\title{
Differential response of planktonic primary, bacterial, and dimethylsulfide production rates to static vs. dynamic light exposure in upper mixed-layer summer sea waters
}

\author{
M. Galí ${ }^{1, *}$, R. Simó ${ }^{1}$, G. L. Pérez ${ }^{2}$, C. Ruiz-González ${ }^{1, * *}$, H. Sarmento ${ }^{1, * * *}$, S.-J. Royer ${ }^{1}$, A. Fuentes-Lema ${ }^{3}$, and J. \\ M. Gasol ${ }^{1}$ \\ ${ }^{1}$ Institut de Ciències del Mar (CSIC), Passeig Marítim de la Barceloneta, 37-49, 08003 Barcelona, Catalonia, Spain \\ ${ }^{2}$ Laboratorio de Ecología y Fotobiología Acuática (IIB-INTECH), Chascomús, Argentina \\ ${ }^{3}$ Departamento de Ecoloxía e Bioloxía Animal, Facultade de Ciencias do Mar, Vigo (Pontevedra), Spain \\ "now at: Takuvik Joint International Laboratory, Université Laval (Canada), CNRS (France), Département de Biologie and \\ Québec-Océan, Université Laval, Pavillon Alexandre-Vachon 1045, avenue de la Médecine G1V 0A6 Québec, Canada \\ ** now at: Département des Sciences Biologiques, Université du Québec à Montréal, Québec, Canada \\ **** now at: Federal University of Rio Grande do Norte, Department of Oceanography and Limnology, "PPg Ecologia", \\ Natal-RN, Brazil
}

Correspondence to: M. Galí (marti.gali.tapias@gmail.com)

Received: 6 May 2013 - Published in Biogeosciences Discuss.: 29 May 2013

Revised: 19 September 2013 - Accepted: 9 October 2013 - Published: 6 December 2013

\begin{abstract}
Microbial plankton experience short-term fluctuations in total solar irradiance and in its spectral composition as they are vertically moved by turbulence in the oceanic upper mixed layer (UML). The fact that the light exposure is not static but dynamic may have important consequences for biogeochemical processes and ocean-atmosphere fluxes. However, most biogeochemical processes other than primary production, like bacterial production or dimethylsulfide (DMS) production, are seldom measured in sunlight and even less often in dynamic light fields. We conducted four experiments in oligotrophic summer stratified Mediterranean waters, where a sample from the UML was incubated in ultraviolet (UV)-transparent bottles at three fixed depths within the UML and on a vertically moving basket across the same depth range. We assessed the response of the phyto- and bacterioplankton community with physiological indicators based on flow cytometry singe-cell measurements, fast repetition rate fluorometry (FRRf), phytoplankton pigment concentrations and particulate light absorption. Dynamic light exposure caused a subtle disruption of the photoinhibition and photoacclimation processes associated with ultraviolet radiation (UVR), which slightly alleviated bacterial photoinhibition but did not favor primary production. Gross DMS
\end{abstract}

production $\left(\mathrm{GP}_{\mathrm{DMS}}\right)$ decreased sharply with depth in parallel to shortwave UVR, and displayed a dose-dependent response that mixing did not significantly disrupt. To our knowledge, we provide the first measurements of $\mathrm{GP}_{\mathrm{DMS}}$ under in situ UV-inclusive optical conditions.

\section{Introduction}

The characteristic response times of microbial plankton match the natural variability of light exposure, which changes at different temporal scales with solar elevation, the passage of clouds, vertical mixing and even wave focusing (Gallegos and Platt, 1985). In transparent oceanic waters, exposure to high irradiance (photosynthetically available radiation, PAR) is accompanied by exposure to detrimental ultraviolet radiation (UVR) in the upper portion of the water column (Vincent and Neale, 2000). Short-term irradiance fluctuations elicit fast and reversible responses (Roy, 2000), whereas continued exposure to high PAR and UVR may elicit photoacclimation (MacIntyre et al., 2002) or permanent physiological changes, i.e., irreversible damage (Buma et al., 2001). 
Vertical mixing can have a positive, neutral or negative effect on water-column-integrated processes depending on the interplay between mixing rates, damage and repair kinetics, and underwater attenuation of PAR and UVR (Neale et al., 2003). In the absence of repair mechanisms, damage will be proportional to cumulative exposure (i.e., it will be dose-dependent). If moderate repair exists, mixing will allow the cells to recover in the UVR shaded portion of the upper mixed layer (UML) (Fig. 1a). In this situation the photodamage will no longer be dose-dependent and a steady state will be achieved provided that the cells spend sufficient time under constant exposure conditions. In the idealized situation where damage is completely counteracted by repair on a timescale much shorter than the mixing time, or in the absence of repair, vertical mixing will have neutral effects. These responses can change with exposure time.

The effects of dynamic light exposure have concerned the aquatic photosynthesis research community for almost $40 \mathrm{yr}$ (see Gallegos and Platt, 1985, and references therein), and apparently contradictory findings have often been reached using either experimental or modeling approaches (Ross et al., 2011a, b). It appears that the ability to take advantage of dynamic light exposure may depend on the taxonomic composition and size structure of the phytoplankton community, their light history, and their nutritional status (Barbieri et al., 2002; Brunet and Lavaud, 2010; Helbling et al., 2013). Knowledge on the photoresponse of (bacterial) heterotrophic activity is much more limited, but a number of studies suggest that significant PAR-driven stimulation frequently occurs (Morán et al., 2001; Church et al., 2004), as does inhibition due to UVR (Aas et al., 1996; Kaiser and Herndl, 1997). There is mounting evidence that UVR resistance and photostimulation responses vary among bacterial phylogenetic groups (Agogué et al., 2005; Alonso-Sáez et al., 2006; RuizGonzález et al., 2012), which might be related to the occurrence of photoheterotrophic metabolisms in the ocean (Kolber et al., 2000; Béjà et al., 2000; Kirchman and Hanson, 2012) or to their interaction with other light-driven processes (see references in Ruiz-González et al., 2013).

Besides carbon and nutrient cycling, solar radiation modulates the biogeochemical cycles of other elements such as sulfur or halogens (Carpenter et al., 2012). The volatile dimethylsulfide (DMS) is produced mainly by the enzymatic cleavage of the phytoplankton osmolyte dimethylsulfoniopropionate (DMSP) as a result of microbial food web interactions (Simó, 2004). Marine DMS emission represents the main natural source of sulfur to the atmosphere (Lana et al., 2011) and has potential implications for climate regulation, which in turn depends on its response to solar radiation (Vallina and Simó, 2007). Yet, the climatic effects of DMS and the underlying atmospheric processes remain highly controversial (Quinn and Bates, 2011; Woodhouse et al., 2013).

The response of community DMS production to sunlight depends on a number of interdependent effects: phytoplankton DMSP production, its intracellular conversion to DMS followed by DMS permeation outside the algal cell, algal DMSP release (due to grazing, cell lysis or active exudation), and DMSP transformations by the microbial food web (Galí et al., 2013a). Phytoplankton culture studies have shown that acclimation to strong UV exposure (and also strong PAR) on a timescale of several days generally causes up-regulation of intracellular DMSP content (Sunda et al., 2002; Slezak and Herndl, 2003), although this view has been challenged (van Rijssel and Buma, 2002). Nutrient limitation (particularly nitrogen) also causes up-regulation of intracellular DMSP (Bucciarelli and Sunda, 2003; Yang et al., 2011), and may interact in complex ways with UVR (Harada et al., 2009). Evidence obtained from culture studies is supported by field observations of higher DMS and DMSP concentrations per unit phytoplankton biomass (and often in absolute terms) during summer stratification (Simó and Pedrós-Alió, 1999; Vila-Costa et al., 2008; Archer et al., 2009). Phytoplankton DMS production is also enhanced by UV exposure (Hefu and Kirst, 1997; Sunda et al., 2002; Archer et al., 2010) and nitrogen limitation (Sunda et al., 2007). Yet, most phytoplankton culture studies have failed to account for photochemical DMS loss, which has precluded a neat assessment of UV effects on phytoplankton DMS production. The ensemble of these observations tends to support the view that DMSP and its metabolites play an antioxidant role in phytoplankton cells (Sunda et al., 2002). In this regard, it is important to note that long- and short-term responses may differ. I.e., a long-term up-regulation response caused by acclimation to oxidative stress is compatible with a short-term decrease in the intracellular DMSP pool due to enhanced DMSP destruction, as observed by Hefu and Kirst (1997) and van Rijssel and Buma (2002). It has recently been shown that sunlight stimulates community gross DMS production (GPDMS ; Galí et al., 2011) in an irradiance- and spectrumdependent manner (Galí et al., 2013a). Moreover, community gross DMS production rates followed the diurnal irradiance cycle in summer stratified waters (Galí et al., 2013b). Phytoplankton radiative stress was the primary explanation invoked by the authors, but food web interactions might also play a role, as thoroughly discussed in those articles.

We designed an experiment where a single surface seawater sample was incubated in UVR-transparent bottles at three fixed optical depths, approximately corresponding to the water subsurface, the optical middle, and the bottom of the UML. An additional set of bottles was regularly moved up and down across the same depth range and radiation gradient (Fig. 1; Table 1). Simulating turbulent mixing experimentally is extremely difficult, and the mixing rates applied to the dynamic incubations were probably not realistic due to being too fast, being constant and having a fixed oscillation period (see Sect. 3.1). Yet, dynamic light exposure might still be more realistic than fixed-depth incubations and provide relevant insights into the photoinhibition and photoacclimation processes occurring in upper mixing waters. The experimental design was aimed at answering two questions 

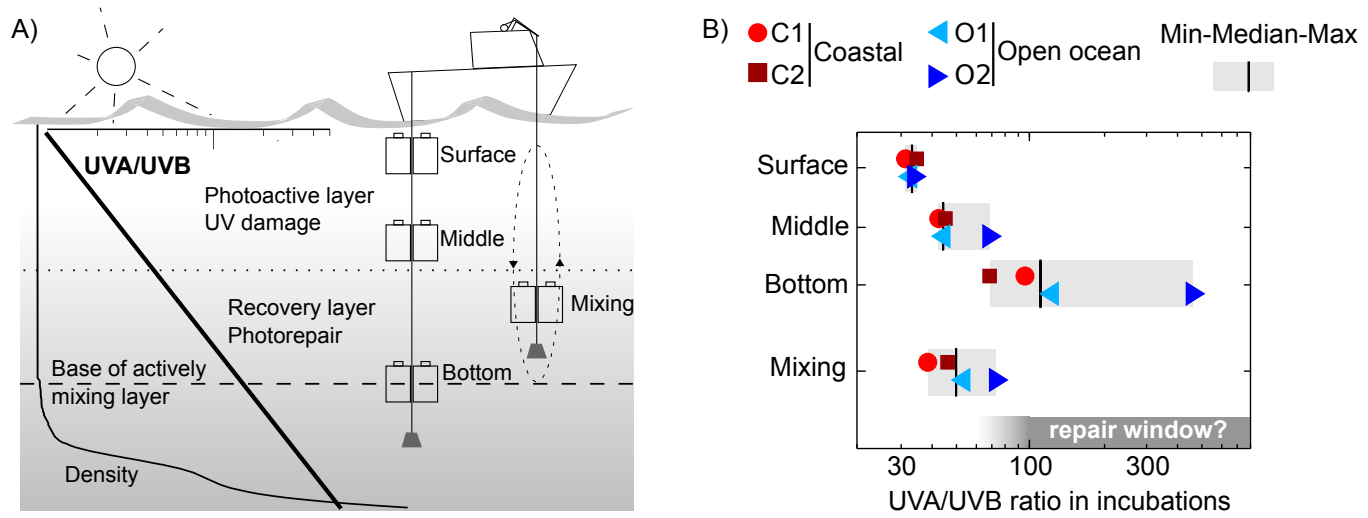

Fig. 1. (a) Illustration of the experimental design. Vertically moving and fixed-depth bottles were incubated in a spectral irradiance gradient, depicted by the UVA/UVB ratio. The dotted and the dashed lines represent the depth of the hypothetical photoactive layer and actively mixing layer, respectively; (b) UVA/UVB in the different treatments in each experiment. The horizontal bar indicates the UVA/UVB window where photolyase repair of bacterioplankton is more efficient, calculated from underwater UVR profiles according to Kaiser and Herndl (1997).

regarding the short-term response of planktonic activity to dynamic light exposure. (1) Photobiological: should the mixing bottles display the same response as the ones incubated at the middle optical depth considering that both treatments received a similar cumulative dose? If the response was the same this would imply that the measured processes were dose-dependent. (2) Biogeochemical and methodological: in UVR-transparent and shallow mixing layers, are the rates obtained from vertical integration of static bottle incubations equivalent to those obtained in vertically moving bottles?

\section{Methods}

\subsection{Experimental setting and irradiance calculations}

Surface ( 0.2 to $3 \mathrm{~m}$ deep) seawater samples were taken predawn in 20-30 L polycarbonate carboys dimmed with a black plastic bag. In the coastal experiments $(\mathrm{C} 1$ and $\mathrm{C} 2)$ the samples were taken from a boat at the Blanes Bay Microbial Observatory coastal site (BBMO; 0.5 miles offshore over a water column depth of $20 \mathrm{~m}$ ), brought to the lab, maintained within $\pm 1{ }^{\circ} \mathrm{C}$ of the sea surface temperature, and incubated at the pier of the Barcelona Olympic Harbor during $4 \mathrm{~h}$ centered on the solar noon. The oceanic experiments (O1 and $\mathrm{O} 2)$ were done in the open Mediterranean during a Lagrangian cruise over a water column depth of ca. $2000 \mathrm{~m}$ (R/V García $\mathrm{del} \mathrm{Cid}$ ). In these experiments the samples were maintained in a thermostated bath at the sea surface temperature until they were incubated in situ (Fig. 1a), beginning $4 \mathrm{~h}$ before solar noon and ending $2 \mathrm{~h}$ after solar noon (with an intermediate sample taken after the first $2 \mathrm{~h}$ ). In $\mathrm{C} 1$ and $\mathrm{C} 2$ mixing was applied by moving the bottle basket (Fig. 1a) manually every $15 \mathrm{~min}$, completing a mixing cycle every $60 \mathrm{~min}$. In the ship-based experiments the mixing bottles were contin- uously moved using the winch of the ship at the smallest possible vertical speed $\left(3-4 \mathrm{~cm} \mathrm{~s}^{-1}\right)$, completing a cycle in 10-18 min. Since the waters were less transparent in the harbor than at the BBMO, in $\mathrm{C} 1$ and $\mathrm{C} 2$ the bottles were incubated at shallower depths to approximate the equivalent in situ optical depths (Table 1). Mixing layer depths (MLD) were estimated from temperature profiles obtained with a conductivity-temperature-depth (CTD) probe, and defined by a $>0.1{ }^{\circ} \mathrm{C}$ deviation with respect to $1 \mathrm{~m}$ depth. The buoyancy or Brunt-Väisälä frequency was calculated in $1 \mathrm{~m}$ bins (Fig. 2), and used as an additional criterion to distinguish the weakly stratified UML from the more stratified waters below.

The irradiance just below the water surface (subsurface irradiance) during the incubations was recorded with a PUV2500 (Biospherical) multichannel filter radiometer, which was also used to measure underwater irradiance profiles in $\mathrm{C} 1$ and $\mathrm{C} 2$. In $\mathrm{O} 1$ and $\mathrm{O} 2$, the vertical profiles were measured with a PRR-800 (Biospherical). Diffuse attenuation coefficients of downward irradiance $\left(K_{\mathrm{d}}\right)$ were calculated as the linear regression between ln-transformed spectral irradiance and depth $(z)$ in the optically homogeneous surface layer where the incubations were done. The time series of subsurface irradiance were converted to the irradiance seen by each water sample by applying the attenuation due to seawater $\left(e^{-K_{\mathrm{d}} \cdot z}\right)$ and the attenuation due to the incubation bottles. We used polytetrafluoroethylene (Teflon, Nalgene) bottles, which according to our measurements transmit $65 \%$, $77 \%$ and $100 \%$ of spectral irradiance in the UVB, UVA and PAR bands, respectively (Galí et al., 2013a). The bottles were placed in a metallic basket which caused a minimal alteration of the tridimensional light field. For the mixing bottles, the irradiance calculation was made using a time-varying depth that corresponded to the vertical displacement of the basket. In each incubation, the mean UVB (300-320 nm) and UVA $(320-400 \mathrm{~nm})$ irradiance was calculated by integrating over 
Table 1. Summary of initial sample characteristics, ecosystem settings and experimental conditions. Phytoplankton group dominance is indicated in a qualitative manner, with biomass calculations made following Simó et al. (2009). All biogeochemical process rates refer to the experimental incubation except for LIR t0, which correspond to the initial sample. GP $\mathrm{DMS}_{\text {and }} \mathrm{NP}_{\mathrm{bio}, \mathrm{DMS}}$ stand for gross and net biological DMS production, respectively. Pro: Prochlorococcus; Syn: Synechococcus; PPeuk: photosynthetic picoeukaryotes; Diat: diatoms; Dino: dinoflagellates; Hapto: haptophytes; na: not available. See text for other abbreviations.

\begin{tabular}{|c|c|c|c|c|}
\hline Experiment code & Coastal $1(\mathrm{C} 1)$ & Coastal $2(\mathrm{C} 2)$ & Oceanic $1(\mathrm{O} 1)$ & Oceanic $2(\mathrm{O} 2)$ \\
\hline Date & 27 Jul 2010 & 29 Jul 2010 & 16 Sep 2011 & 20 Sep 2011 \\
\hline Sampling position & \multicolumn{2}{|c|}{$41.67 \mathrm{~N} 2.81 \mathrm{E}$} & $40.9 \mathrm{~N} 2.67 \mathrm{E}$ & $40.9 \mathrm{~N} 2.44 \mathrm{E}$ \\
\hline \multicolumn{5}{|c|}{ Physicochemical characteristics of the upper mixed layer } \\
\hline $\operatorname{SST}\left({ }^{\circ} \mathrm{C}\right)$ & 23.0 & 22.7 & 25.2 & 23.6 \\
\hline Nitrate + nitrite $\left(\mu \mathrm{molL}^{-1}\right)$ & 0.53 & 0.67 & 0.03 & 0.04 \\
\hline Phosphate $\left(\mu \mathrm{molL}^{-1}\right)$ & 0.08 & 0.15 & 0.06 & 0.06 \\
\hline Silicate $\left(\mu \mathrm{molL}{ }^{-1}\right)$ & 0.77 & 1.05 & 0.53 & 0.59 \\
\hline $\operatorname{MLD}(\mathrm{m})$ & 4 & 3 & 7 & 16 \\
\hline Z $10 \% 320 \mathrm{~nm}(\mathrm{~m})$ & 7 & 7 & 12 & 11 \\
\hline$Z 10 \% 380 \mathrm{~nm}(\mathrm{~m})$ & 20 & 20 & 38 & 32 \\
\hline Buoyancy frequency $\left(\mathrm{h}^{-1}\right)$ & $6.2 \pm 1.7$ & $8.8 \pm 2.7$ & $8.1 \pm 2.8$ & $4.9 \pm 0.9$ \\
\hline Wind speed $\left(\mathrm{ms}^{-1}\right)$ & $2.4-6.7$ & $1.4-7.1$ & $0.3-4.8$ & $1.0-9.5$ \\
\hline UVB range $\left(\mathrm{Wm}^{-2}\right)$ & $0.4-1.4$ & $0.4-1.1$ & $0.3-1.1$ & $0.04-1.1$ \\
\hline UVA range $\left(\mathrm{W} \mathrm{m}^{-2}\right)$ & $22-37$ & $21-31$ & 19-30 & $9-30$ \\
\hline PAR range ( $\mu$ mol phontons $\left.\mathrm{m}^{2} \mathrm{~s}^{-1}\right)$ & $1100-1580$ & $1010-1330$ & $830-1360$ & $410-1340$ \\
\hline \multicolumn{5}{|l|}{ Experimental conditions } \\
\hline Incubation depth (m) & $0.3,1,3$ & $0.5,1.5,3.5$ & $0.5,3,11$ & $0.5,5.5,18$ \\
\hline Equivalent depth UVB (m) & $1.3,4,10$ & $1.3,3.5,6$ & $2.5,5,13$ & $2.5,7,20$ \\
\hline Mixing time (min) & 60 & 60 & 18 & 10 \\
\hline UVB range $\left(\mathrm{W} \mathrm{m}^{-2}\right)$ & $0.04-0.9$ & $0.13-0.7$ & $0.09-0.7$ & $0.01-0.65$ \\
\hline UVA range $\left(\mathrm{W} \mathrm{m}^{-2}\right)$ & 4-28 & 9-24 & $11-23$ & $5-22$ \\
\hline PAR range $(\mu \mathrm{E})$ & $460-1930$ & $600-1210$ & $610-1360$ & $320-1290$ \\
\hline \multicolumn{5}{|l|}{ Initial sample characteristics } \\
\hline DMS $\left(\mathrm{nmolL}^{-1}\right)$ & 7.5 & 8.5 & 2.1 & 2.1 \\
\hline DMSPt $\left(\mathrm{nmolL}^{-1}\right)$ & 23.0 & 18.5 & 18.2 & 19.6 \\
\hline Chl $a\left(\mu g \mathrm{~L}^{-1}\right)$ & 0.24 & 0.25 & 0.08 & 0.08 \\
\hline Dominant phytoplankton (biomass) & \multicolumn{2}{|c|}{ PPeuk $>$ Diat $>$ Pro } & \multicolumn{2}{|c|}{ Syn > Dino > PPeuk (Hapto) } \\
\hline Bacteria $\left(10^{5}\right.$ cells mL $\left.\mathrm{mL}^{-1}\right)$ & 9.0 & 7.3 & 9.4 & 7.3 \\
\hline Intact-membrane bacteria $(\%)$ & 54 & 52 & 56 & 56 \\
\hline \multicolumn{5}{|c|}{ Biogeochemical process rates (min-max) } \\
\hline $\operatorname{PPp}\left(\mathrm{nmolCL}^{-1} \mathrm{~h}^{-1}\right)$ & $80-150$ & $160-200$ & $20-26$ & $21-25$ \\
\hline LIR $t_{0}\left(\right.$ pmolleu $\left.\mathrm{L}^{-1} \mathrm{~h}^{-1}\right)$ & 32 & 21 & 36 & 18 \\
\hline LIR (pmolleu $\left.\mathrm{L}^{-1} \mathrm{~h}^{-1}\right)$ & $33-37$ & $16-21$ & $37-44$ & $17-27$ \\
\hline $\mathrm{GP}_{\mathrm{DMS}}\left(\mathrm{nmolDMSL} \mathrm{L}^{-1} \mathrm{~h}^{-1}\right)$ & $0.05-0.40$ & $0.24-0.49$ & na & $0.07-0.17$ \\
\hline $\mathrm{NP}_{\text {bio,DMS }}\left(\mathrm{nmolDMSL}^{-1} \mathrm{~h}^{-1}\right)$ & $0.03-0.32$ & $0.18-0.44$ & $0.02-0.10$ & $0.04-0.16$ \\
\hline
\end{tabular}

the spectrum the mean spectral irradiance in the 6 bands measured by the PUV-2500 (centered at 305, 313, 320, 340, 380 and $395 \mathrm{~nm}$ ) as described by Galí et al. (2013a). PAR was measured in a single integrated band (400-700 nm) so that no spectral integration was required. The irradiance dose was calculated by multiplying the mean irradiance by the total incubation time.

\subsection{Process measurements and analysis techniques}

Primary production was measured as the ${ }^{14} \mathrm{C}$ incorporated into particles in duplicate $40 \mathrm{~mL}$ Teflon bottles inoculated with $\mathrm{NaH}^{14} \mathrm{CO}_{3}$ (Morán et al., 1999) and incubated in situ (including dark controls).

Bacterial heterotrophic production rates were measured as ${ }^{3} \mathrm{H}$-leucine incorporation rates (LIRs; Kirchman et al., 1985; 


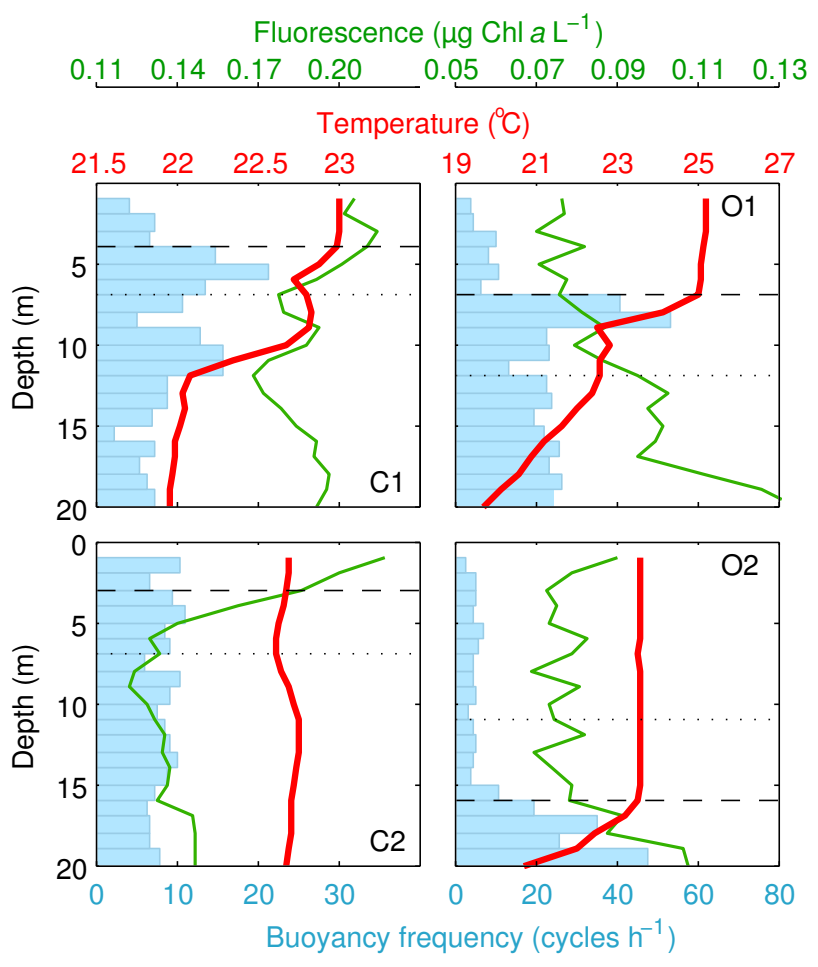

Fig. 2. Vertical profiles of temperature, Chl $a$ fluorescence and buoyancy (Brunt-Väisälä) frequency at the time of sampling in the four experiments. The horizontal dashed line indicates the depth of the mixing layer and the dotted line the $10 \%$ penetration of $320 \mathrm{~nm}$ radiation (see also Table 1).

Smith and Azam, 1992) in the initial samples and on subsamples taken from the larger $(2.3 \mathrm{~L})$ Teflon incubation bottles after in situ light exposure. Triplicate subsamples plus one killed control from each Teflon bottle were further incubated for $2 \mathrm{~h}$ in the dark at in situ temperature in $1.5 \mathrm{~mL}$ Eppendorf vials. In $\mathrm{C} 1$ and $\mathrm{C} 2$, LIRs were measured only in initial and final (4h) samples. In O1 and O2, incubation-averaged LIRs were calculated as the time-weighted average of intermediate $(2 \mathrm{~h})$ and final time $(6 \mathrm{~h})$ incubations. We assumed the intermediate LIR measurement to represent the initial $2 \mathrm{~h}$ exposure, and the final LIR measurement the subsequent $4 \mathrm{~h}$ period. In $\mathrm{C} 1$ and $\mathrm{C} 2$ leucine incorporation was also measured during "in situ" sunlit incubations in $40 \mathrm{~mL}$ Teflon bottles to which ${ }^{3} \mathrm{H}$-leucine had been added.

Samples for pigment analysis were obtained by filtering 1$2 \mathrm{~L}$ seawater onto GF/F filters at the beginning and the end of the incubations ( $\mathrm{O} 1$ and $\mathrm{O} 2$ only) and the filters were immediately stored in liquid nitrogen. Pigments were extracted and analyzed by HPLC following Zapata et al. (2000) on a SpectraSYSTEM (Thermo) using a Waters Symmetry C8 column $(150 \times 4.6 \mathrm{~mm}, 3.5 \mu$ particle size, $10 \mathrm{~nm}$ pore size $)$. Calibration was made using commercial external pigment standards (DHI, Denmark), and the pigments were identified according to their elution time.
The absorption spectra of total particulate matter $a_{\mathrm{p}}$ were determined by the quantitative filter technique, using the simple transmittance method in a Lambda 800 (Perkin-Elmer) spectrophotometer. Water samples $(2 \mathrm{~L})$ were filtered onboard using $25 \mathrm{~mm}$-diameter $\mathrm{GF} / \mathrm{F}$ filters. Immediately after filtration absorbance scans were measured from 350 to $750 \mathrm{~nm}$ at $1 \mathrm{~nm}$ intervals. The quantitative filter technique was applied according to NASA's optics protocols for absorption coefficient measurements (Mitchell et al., 2000). In order to minimize light scattering, the wet filters were placed as close to the spectrophotometer detector as possible and measured against a blank clean filter wetted with filtered $(0.2 \mu \mathrm{m})$ seawater. Absorption coefficients were estimated according to the relationship $a_{\mathrm{p}}(\lambda)=\frac{2.303 A_{\text {filter }}(\lambda) s}{V_{\text {filt }} \beta(\lambda)}$, where $A_{\text {filter }}(\lambda)$ is the measured absorbance, $s$ is the clearance area of the filter, $V_{\text {filt }}$ is the volume of filtered water, and $\beta(\lambda)$ is the amplification factor vector (Mitchell and Kiefer, 1984).

The maximum quantum yield of photosystem II photochemistry $\left(F_{\mathrm{v}} / F_{\mathrm{m}}\right)$, an indicator of phytoplankton photosynthetic performance and photoinhibition, was measured by fast repetition rate fluorometry (FastTracka I, Chelsea), as detailed by Galí et al. (2013a).

A FACSCalibur (Becton \& Dickinson) flow cytometer equipped with a $15 \mathrm{~mW}$ Argon-ion laser (488 nm emission) was used to enumerate picophyto- and bacterioplankton populations and to measure their performance at the single-cell level. The cell-specific fluorescence of each different picophytoplankton population (normalized to their side scatter - SSC, a proxy for cell size) was measured following Marie and Partensky (2006). At least 30000 events were acquired for each subsample. Fluorescent beads $(1 \mu \mathrm{m}$, Fluoresbrite carboxylate microspheres, Polysciences Inc., Warrington, PA, USA) were added at a known density as internal standards. Two subpopulations of heterotrophic bacterioplankton were distinguished based on the nucleic acid double-staining (NADS) viability protocol: intact-membrane (or "live") bacteria and membrane-compromised (or "dead") bacteria (Grégori et al., 2001). This protocol uses a combination of the cell-permeant nucleic acid stain SybrGreen I (SGI, Molecular Probes, Eugene, OR, USA) and the cellimpermeant propidium iodine (PI, Sigma Chemical Co.) fluorescent probe. We used a $1: 10$ SGI and $10 \mu \mathrm{g} \mathrm{mL}^{-1} \mathrm{PI}$ concentrations that were added to live samples less than $2 \mathrm{~h}$ after sampling. After simultaneous addition of each stain, the samples were incubated for $20 \mathrm{~min}$ in the dark at room temperature and then analyzed.

DMS and total DMSP (DMSPt) were measured by purge and trap gas chromatography (Shimadzu GC14A) coupled to flame photometric detection. Net biological DMS production $\left(\mathrm{NP}_{\text {bio,DMS }}\right)$ was obtained by incubating whole water samples in $2.3 \mathrm{~L}$ Teflon bottles and correcting afterward for photochemical DMS loss, as described by Galí et al. (2013a). Gross DMS production was measured in the same way in additional bottles amended with $200 \mu \mathrm{mol} \mathrm{L}^{-1}$ 


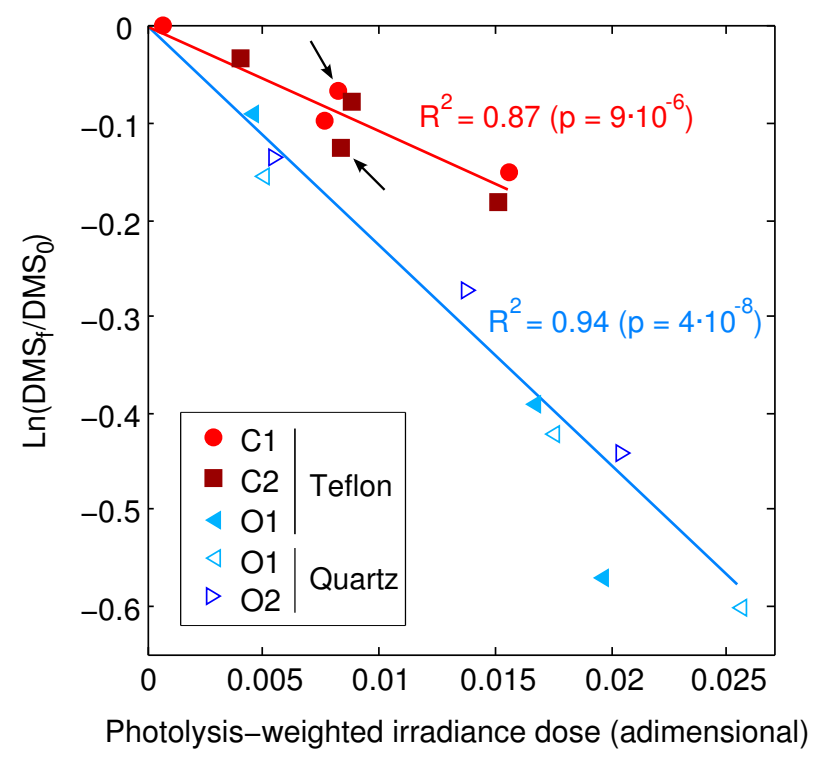

Fig. 3. DMS photolysis in fixed and vertically moving incubations. The two types of incubation showed consistent dose-response behavior. Filled symbols: Teflon bottles incubated in $\mathrm{C} 1$ and $\mathrm{C} 2$ at three fixed depths and in a vertically moving basket (marked by arrows). Empty symbols: Teflon or quartz flasks incubated on board and withdrawn at different times (samples taken on three different days during the SUMMER-I cruise). The slope of the regression lines is $k^{*}$ photo: the apparent quantum yield of DMS photolysis with respect to weighted spectral UV irradiance normalized to $300 \mathrm{~nm}$ (as defined by Galí et al., 2013a). $k^{*}$ photo was 10.8 and 23.9 at the coastal station and at the oceanic station, respectively.

dimethyldisulfide (Galí et al., 2011), an effective inhibitor of bacterial DMS consumption (Wolfe and Kiene, 1993; Simó et al., 2000).

DMS photolysis was measured in $0.2 \mu \mathrm{m}$ filtered-water incubations in $40 \mathrm{~mL}$ Teflon bottles or $50 \mathrm{~mL}$ quartz flasks. As expected, DMS photolysis was linearly related to the photochemically weighted irradiance dose (Fig. 3). Since we observed distinct DMS photolysis yields in coastal (C1-C2) versus oceanic (O1-O2) experiments, a distinct photolysis rate constant $\left(k_{\text {photo }}^{*}\right)$ for each type of experimental location (i.e., coastal or oceanic) was used to correct the biological rates for photochemical DMS loss.

The process rates and indicator variables were measured in duplicate with the exceptions of DMS production rates, pigment concentrations and particulate absorption coefficients due to water volume constraints. The measurement of DMS production rates requires large incubation volumes to properly account for food web processes like microzooplankton grazing (Saló et al., 2010).

\subsection{Statistical analyses}

Each variable was normalized within each experiment to the vertical integral of the fixed incubations. The integration was calculated as the area under the trapezoids formed by depth vs. rate data points. After pooling the four experiments together we checked for significant differences among treatments $(\mathrm{d} f=3)$. If the Bartlett's equal variance test was successfully passed $(p>0.05)$ a parametric one-way analysis of variance (ANOVA) was used. Otherwise, a non-parametric Kruskal-Wallis ANOVA was performed. After a significant ANOVA $(p<0.05)$ multiple comparisons were done with the Tukey-Kramer test.

\section{Results and discussion}

\subsection{Oceanographic settings}

The sampled UML was in all cases exposed to high proportions of UVR, i.e., > $10 \%$ of the subsurface UVA and UVB levels. Only in $\mathrm{C} 2$ the deeper portion of the UML was exposed to $<10 \%$ of subsurface UVB (Fig. 2; Table 1). The phytoplankton community was typical of oligotrophic conditions, with low biomass and large contributions of the pico-sized fraction (Prochlorococcus, Synechococcus and picoeukaryotes) though in different proportions (Table 1). The picoeukaryote fraction was likely dominated by haptophytes (prymnesiophytes) and pelagophytes in $\mathrm{O} 1$ and $\mathrm{O} 2$ according to HPLC pigment data (Pérez et al., unpublished). Diatoms in $\mathrm{C} 1$ and $\mathrm{C} 2$ and small dinoflagellates $(<10 \mu \mathrm{m})$ in $\mathrm{O} 1$ and $\mathrm{O} 2$ also made significant contributions to total phytoplankton biomass.

The mixing layer was very shallow at the coastal site (MLD of 3-4 m). In the oceanic setting, the UML deepened from $7 \mathrm{~m}(\mathrm{O} 1)$ to $16 \mathrm{~m}(\mathrm{O} 2)$ due to the passage of a storm (Fig. 2). The fact that all experiments took place in soft wind conditions, and the relatively high values of the buoyancy (Brunt-Väisälä) frequency within the UML suggest that it was not mixing actively at the time of the CTD casts (Table 1). If we assume that vertical diffusivity $\left(K_{z}\right)$ in the UML interior was in the range $10^{-2}-10^{-4} \mathrm{~m}^{2} \mathrm{~s}^{-1}$ (Denman and Gargett, 1983; Ross et al., 2011b), it would take ca. 0.25 to $100 \mathrm{~h}$ for a population of particles released at a single depth to diffuse across one optical depth in the UML depending on the wavelengths and MLD considered (Gallegos and Platt, 1985). A similar range is obtained by calculating the mixing timescale as $\mathrm{MLD}^{2} / K_{z}$ as suggested by Ross et al. (2011a, b). The highest $K_{z}$ might be representative of nighttime convective overturning, while the lowest $K_{z}$ might be more representative of the daytime, when mixing was likely inhibited by solar heating (Brainerd and Gregg, 1995). From these calculations we conclude that the simulated mixing times were considerably faster than the actual mixing times. Although we tried to simulate the optical gradient experienced by the 
organisms and solutes within the UML, in practice the incubations spanned a larger optical gradient once the attenuation due to seawater and the incubation bottles was taken into account (Table 1).

Indeed, some of the differences between experiments and particularly between $\mathrm{O} 1$ and $\mathrm{O} 2$ may arise from slight differences in experimental exposure and prior light history of the plankton. Yet, our discussion will focus on the general trends rather than the differences among individual experiments.

\subsection{Phytoplankton photosynthetic performance and photoacclimation}

Particulate primary production ( $\mathrm{PPp}$ ) was moderately inhibited at the surface, optimal at the middle depth, and slightly lower at the bottom, with the exception of C1 (Fig. 4a). PPp in mixing bottles resembled that in surface bottles and was $18 \%$ lower than in middle bottles except in $\mathrm{C} 1(p<0.01)$. As a result, vertically integrated PPp from fixed bottles generally exceeded that in mixing bottles by $10-17 \%$ (except in C1). This result contrasts with that obtained by Bertoni et al. (2011), who observed a neutral to positive effect of dynamic light exposure in coastal Mediterranean waters in late spring. The response of primary production may be explained by different photoacclimation, photoprotection and damage and repair processes that will be explored in the paragraphs below.

At the end of the incubations, the average fluorescence of Synechococcus and picoeukaryote cell populations was generally lowest at the surface and increased with depth (Fig. 4b, c). Fluorescence was generally lower than average in mixing bottles (although different patterns were observed for picoeukaryotes in O2). Similar responses were observed for nanoeukaryotes in $\mathrm{C} 2$ and for Prochlorococcus in $\mathrm{O} 1$ (data not shown). In addition, we observed a ca. $30 \%$ decrease in Prochlorococcus cell counts likely due to UV-caused mortality in surface bottles, as previously shown by Sommaruga et al. (2005). In concordance with the response of populations analyzed with single-cell techniques, bulk phytoplankton $F_{\mathrm{v}} / F_{\mathrm{m}}$ tended to increase with incubation depth (Fig. $4 \mathrm{~d}$ ). $F_{\mathrm{v}} / F_{\mathrm{m}}$ in mixing bottles was (again) lower than the vertical integral of fixed bottles in $\mathrm{C} 1$ and $\mathrm{O} 1$, but not in $\mathrm{O} 2$, potentially due to the high fluorescence yields of the picoeukaryote population (Fig. 4c). The decrease in fluorescence yields may simultaneously result from a decrease in chlorophyll $a(\mathrm{Chl} a$ ) content per cell (MacIntyre et al., 2002), an increase in excess energy dissipation as heat by photoprotective carotenoids (non-photochemical quenching), photodamage of photosystem II, and pigment bleaching (Vincent and Neale, 2000).

Chl $a$ concentrations generally increased (by 10-30\%) during the experiments except in $\mathrm{O} 1$, where a ca. $20 \%$ decrease was found. In $\mathrm{O} 1$ and $\mathrm{O} 2$, the ratio of photosynthetic carotenoids to $\mathrm{Chl} a$ ( $\mathrm{PC} / \mathrm{Chl} a$ ) increased with depth, from ca. 0.48 at the surface to ca. 0.56 in bottom bottles. PC/ Chl $a$ in mixing bottles was close to the vertical integral of fixed bottles (Fig. 4e). This suggests that phytoplankton photoacclimated during the time frame of the experiment $(6 \mathrm{~h})$ by adjusting PC/ $\mathrm{Chl} a$ to the average spectral irradiance they were exposed to, likely seeking to optimize photosynthesis. Another physiological indicator that is worth analyzing is the ratio of photosynthetic carotenoids to non-photosynthetic carotenoids (PC/NPC; Fig. 4f), as defined by Bricaud et al. (1995). In the fixed bottles, this ratio increased from about 0.66 to 0.90 from surface to bottom. At the surface, the low PC / NPC values were due to the net synthesis of NPC (with a $20-40 \%$ increase during the incubation). These results indicate an increasing investment in photoprotection through non-photochemical quenching at higher spectral irradiance. This is consistent with the decrease in photosystem II fluorescence yields (Fig. 4d), since NPC compete for excitation energy with the other energy dissipation pathways: photochemistry and fluorescence emission. Surprisingly, mixing bottles displayed the highest values of PC / NPC due to higher-thanaverage PC concentrations, a response that remains difficult to interpret.

The xanthophyll cycle pigments diadinoxanthin (Dd) and diatoxanthin (Dt) were up-regulated by about $35 \%$ (up to $75 \%$ ) during the exposure relative to their initial concentration. Likewise, $(\mathrm{Dd}+\mathrm{Dt})$ concentrations relative to $\mathrm{Chl}$ $a$ increased by $50 \%$ in the ensemble of all treatments in $\mathrm{O} 1$ and $\mathrm{O} 2 .(\mathrm{Dd}+\mathrm{Dt}) / \mathrm{Chl} a$ generally increased towards the surface, and showed intermediate values in mixing bottles (Fig. 4h). These xanthophylls constitute a photoprotective mechanism in haptophytes, dinoflagellates and diatoms (van de Poll and Buma, 2009) by which the epoxidated form (Dd) is enzymatically de-epoxidated to Dt, and vice versa, depending on the cells' need for photoprotection. No clear trends were observed in the de-epoxidation state index, defined as $\mathrm{Dt} /(\mathrm{Dd}+\mathrm{Dt})$, perhaps because the Dt vs. Dd interconversion responds on a timescale of few minutes (van de Poll and Buma, 2009), which is shorter than the filtration time of the samples after the exposure.

UV-absorbing (sunscreen) compounds, possibly mycosporine-like amino acids (Shick and Dunlap, 2002), were observed in particulate absorption spectra in $\mathrm{O} 1$ and O2 (Fig. 4i). The ratio of particulate light absorption at $340 \mathrm{~nm}$ relative to that at the blue peak of Chl $a$ at $440 \mathrm{~nm}$, $a_{\mathrm{p}, 340} / a_{\mathrm{p}, 440}$, was highest (1-1.5) in surface bottles and lower (0.7-0.8) in middle and bottom bottles. Mixing bottles showed an ambiguous response, with low $a_{\mathrm{p}, 340} / a_{\mathrm{p}, 440}$ in $\mathrm{O} 1$ and slightly higher $a_{\mathrm{p}, 340} / a_{\mathrm{p}, 440}$ in $\mathrm{O} 2$.

The several photoresponse indicators we have explored indicate that, although phytoplankton deployed different photoprotection mechanisms, these were not enough to counteract high PAR- and UV-driven photoinhibition in surface bottles. Seen another way, the investment in photoprotection might have decreased the allocation of resources to carbon fixation. In middle bottles, conversely, the combination of high PAR and longwave UVA, which can also be used for photosynthesis, (Helbling et al., 2003) and a lower 


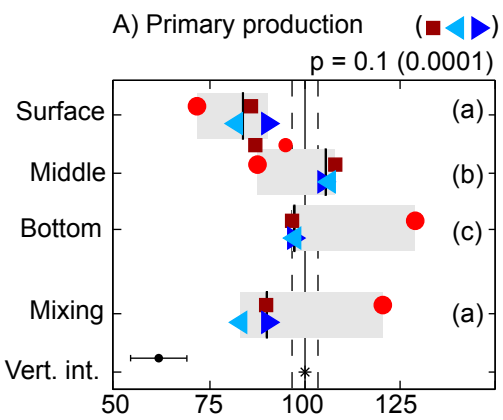

B) Flu/SSC Synechococcus
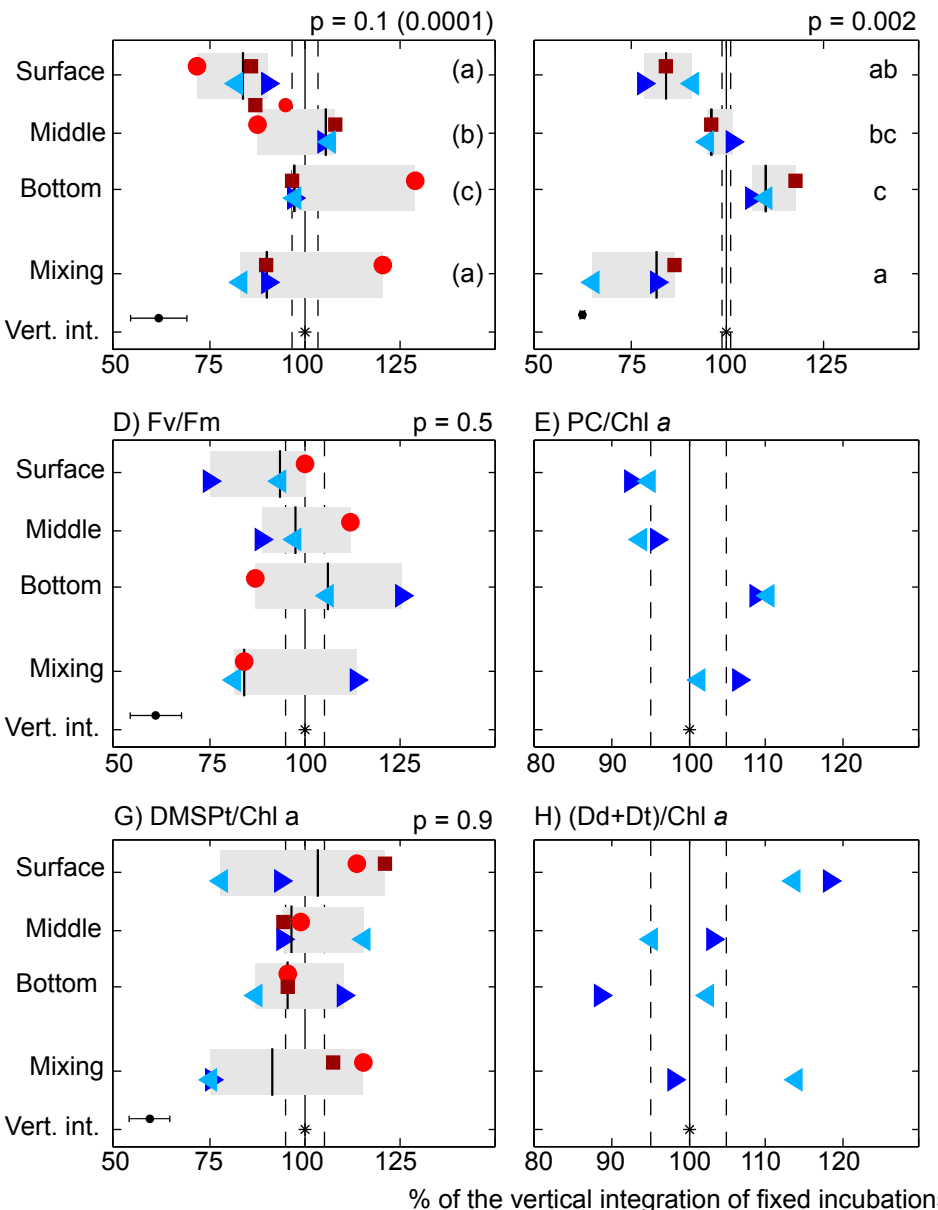

C) Flu/SSC Picoeukaryotes

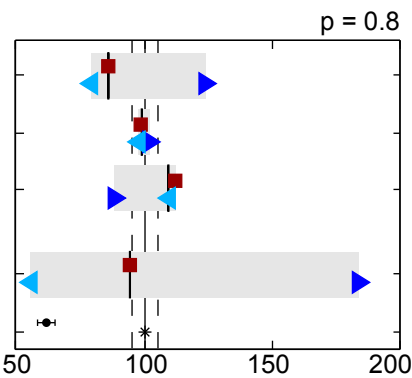

F) PC/NPC
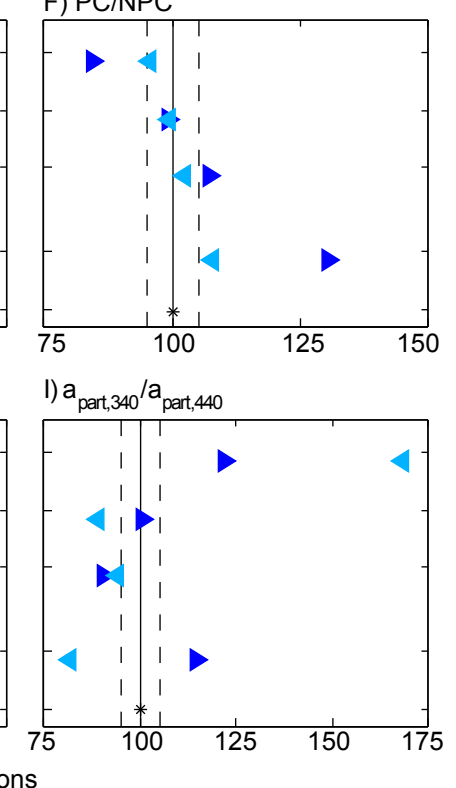

Min-Median-Max

* Mean and error of vertical integration

- Mean measurement error

Fig. 4. Response of phytoplankton to irradiance gradients in static and vertically moving incubations. Primary production rates (a) and indicators of phytoplankton photoresponse $(\mathbf{b}-\mathbf{i})$ have been normalized, within each experiment, to the vertical integral of fixed incubations. Flu / SSC: side-scatter-normalized cell-specific fluorescence. $F_{\mathrm{V}} / F_{\mathrm{m}}$ : maximum quantum yield of photosystem II photochemistry. PC: photosynthetic carotenoids. NPC: non-photosynthetic carotenoids. Dd: diadinoxanthin. Dt: diatoxanthin. $a_{\mathrm{p}, 340} / a_{\mathrm{p}, 440}:$ ratio of particulate light absorption coefficient at $340 \mathrm{~nm}$ and $440 \mathrm{~nm}$. Differences between treatments are represented by $p$ values of ANOVA tests followed by multiple comparisons (see text for details). In (a), a test was performed on a subset of experiments (C2, O1 and O2) that exhibited a more coherent response, and the resulting $p$ value and multiple comparisons are shown in parentheses.

investment in photoprotection due to lower proportions of UVR resulted in optimal PPp. It is also important to bear in mind that different phytoplankton groups likely preferred different photoprotection mechanisms within those cited.

The response of mixing bottles is more difficult to interpret. The reduced photosynthetic performance in $\mathrm{C} 2, \mathrm{O} 1$ and $\mathrm{O} 2$ might indicate that the short surface exposure received by mixing bottles was enough to cause some irreversible inhibition, and that phytoplankton repair capacity was limited. However, this is not clearly supported by the radiative stress indicators measured. In addition, repair is thought to be more efficient at elevated temperatures like those encountered in our study (Campbell et al., 1998; van de Poll and Buma, 2009). The fact that surface inhibition was only moderate and that highest PPp occurred in the middle bottle suggests that the photosynthetic machinery of phytoplankton was well adapted to a stratified system and thus not geared to take advantage of fast changes in spectral irradiance. This contrasts with what has been found for coastal tropical phytoplankton thriving in turbid waters (Helbling et al., 2003) or even for coastal Mediterranean assemblages in late spring (Bertoni et al., 2011). 


\subsection{Response of bacterial heterotrophic production}

In fixed bottle incubations, LIRs were significantly inhibited at the surface by $14-28 \%$ with respect to the vertical integral (except in C1), and increased with depth to find their optimum at the bottom of the mixed layer (Fig. 5a). LIRs in mixing bottles resembled those of bottom bottles in 3 out of 4 experiments, and were higher (though not significantly) than those in middle bottles and the vertical integral. This suggests that fast mixing favored recovery and photorepair over photodamage. It is well known that photolyase enzymes use UVA and blue light to repair damaged DNA. According to Kaiser and Herndl (1997), optimal photoreactivation occurs in a certain window of UVA/UVB that, in our experiments, would roughly correspond to the bottom half of the UML (Fig. 1b). This interpretation is supported by the higher proportions of intact-membrane bacteria found in mixing bottles at the end of the incubations with respect to the surface bottles (O1 and $\mathrm{O} 2$ only; Fig. 5c). Yet, the vertical trend shown by this cytometric indicator in fixed bottles contradicts this view, especially in $\mathrm{O} 2$, where the proportion of intact-membrane bacteria decreased with depth.

In addition to the post-exposure dark incubations, in $\mathrm{C} 1$ and $\mathrm{C} 2$ we measured LIRs during the sunlit incubations, i.e., with the ${ }^{3} \mathrm{H}$-leucine added into exposed bottles (Fig. 5b). In these "in situ" incubations, surface and mixing bottles displayed more similar degrees of inhibition, and the trends of bacterial production with depth did not match those found in post-exposure dark incubations. We also measured LIRs in aluminum-foil-darkened bottles placed in the in situ incubation basket. Dark LIR was $22 \%$ higher than the vertical integral of sunlit bottles in $\mathrm{C} 1$, but no differences were observed in C2 (Fig. 5b). The discrepancies between in situ and postexposure leucine incorporation may be due to distinct photoinhibition and photorepair dynamics, and each approach has advantages and disadvantages. The tendency of in situ leucine incorporation to display less photoinhibition may be due to substrate incorporation at the beginning of the incubation, before the onset of severe photoinhibition. On the other hand, post-exposure LIRs reflect the photoinhibition state at the end of the exposure, resulting from the net balance between damage and repair in sunlight as well as from the net repair that might occur during the $2 \mathrm{~h}$ post-exposure dark incubation. These methodological issues might be overcome with the development of more sensitive methods that allow a faster determination of bacterial heterotrophic production, which is particularly challenging in oligotrophic waters with low activity.

Different explanations have been invoked to explain the responses of bacterial activity under sunlight, for instance, the occurrence of photoheterotrophic metabolisms in some bacterial groups, or the exudation of labile organic matter by phytoplankton at high irradiance (reviewed by RuizGonzález et al., 2013). Unfortunately, we did not investigate the phylogenetic composition of the bacterial communities in our experiments. No obvious patterns linking the response of LIR and PPp were found, perhaps because phytoplanktonbacteria interactions through the dissolved carbon pool are complex and group-specific (Sarmento and Gasol, 2012). Despite the numerous uncertainties, our study adds valuable information to the only previous study of bacterial production under dynamic light exposure (Bertoni et al., 2011), and agrees with that work in that the effect of mixing was neutral to positive compared to fixed incubations.

\subsection{Response of community DMS production}

Gross DMS production (GP $\mathrm{DMS}_{\mathrm{DMS}}$ ) showed the strongest vertical gradient among the three processes, and increased significantly by about three-fold between the bottom and the surface of the UML in fixed incubations (Fig. 6a). Gross DMS production in mixing bottles was not significantly different from that in middle bottles, nor from the vertical integral, although a slight trend towards lower $\mathrm{GP}_{\mathrm{DMS}}$ in mixing bottles occurred in $\mathrm{C} 1$ and $\mathrm{C} 2$.

Gross DMS production results from the addition and interaction of several processes, namely exudation of DMS by phytoplankton, bacterial degradation of DMSP released by phytoplankton as a result of grazing, viral infection, or cell death, and even the reduction of dimethylsulfoxide (Spiese et al., 2009; Asher et al., 2011). Galí et al. (2013a) showed that UVR stimulates GP ${ }_{\text {DMS }}$ in a spectral irradiancedependent manner, a result that is confirmed by our present study. They also demonstrated that the stimulation is more effective at shorter and more energetic UVR wavelengths, with a spectral peak around $330 \mathrm{~nm}$, and attributed the stimulation effect to phytoplankton DMS release caused by the additive effects of excess PAR (Stefels, 2000) and UVR stress (Sunda et al., 2002). Furthermore, it was suggested that lethal UVR exposure could promote DMS production as a result of phytoplankton cell lysis and subsequent DMSP release. This mechanism would make more DMSP available to bacteria and to algal DMSP cleavage enzymes ("lyases") released along with algal DMSP.

In the ensemble of all the experiments, experimentnormalized PPp and GP DMS $_{\text {were negatively correlated }}$ (Pearson's $r=-0.58 ; p=0.018$; Spearman's $\rho=-0.51$; $p=0.044)$. Moreover, the response of $\mathrm{GP}_{\mathrm{DMS}}$ to radiative stress was generally consistent with the patterns of photoinhibition and photoprotection (Archer et al., 2010). Whether or not this response was the result of active physiological regulation of phytoplankton cells remains to be elucidated. Clearly, better methods are needed to study the relative weight of different DMS production processes and their modulation by spectral irradiance (Galí et al., 2013a). Sunda et al. (2002) suggested that intracellular DMSP cleavage to DMS plus acrylate and further oxidation products might help phytoplankton cells coping with oxidative stress. If we assume that the UV-driven increase in $\mathrm{GP}_{\mathrm{DMS}}$ arose completely from up-regulated intracellular DMSP cleavage, which is 


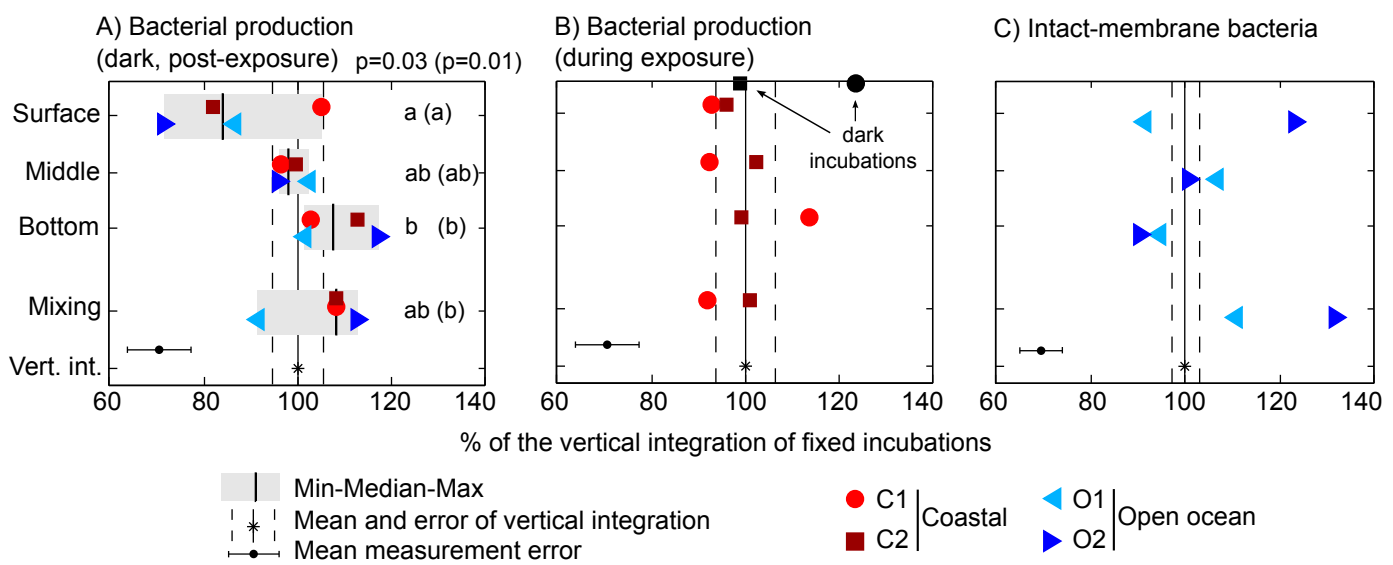

Fig. 5. Response of heterotrophic bacteria to irradiance gradients in static and vertically moving incubations. Leucine incorporation rates in (a) post-exposure dark incubations and (b) in situ light and dark incubations; (c) proportion of intact-membrane ("live") bacteria as deduced from the nucleic acid double-staining (NADS) protocol. Statistical comparisons as in Fig. 4. In (a), a test was performed on a subset of experiments $(\mathrm{C} 2, \mathrm{O} 1$ and $\mathrm{O} 2)$ that exhibited a more coherent response, and the resulting $p$ value and multiple comparisons are shown in parentheses.

A) Gross DMS production

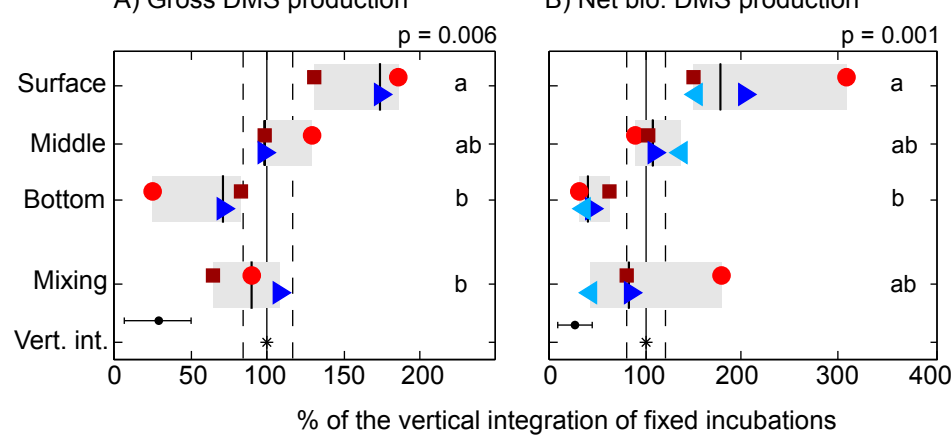

| Min-Median-Max

I $*$ Mean and error of vert. int.

$\longmapsto$ Mean measurement error

- $\quad$ C1 2 Coastal

O1
$-\quad$ O2| Open ocean

Fig. 6. Response of community DMS production to irradiance gradients in static and vertically moving incubations. (a) Gross DMS production (GP $\mathrm{DMS}_{\mathrm{DMS}}$, DMDS-amended incubations); (b) net biological DMS production (non-amended incubations; equivalent to GP $\mathrm{DMS}_{\mathrm{DM}}$ minus bacterial DMS consumption). Statistical comparisons as in Fig. 4. In (b), a test was performed on a subset of experiments (C2, O1 and O2) that exhibited a more coherent response. Multiple comparisons did not show different patterns from those in the entire data set, although the $p$ value decreased $(p=0.0008)$.

very unlikely, our data suggest that this antioxidant mechanism would still not be enough to counteract short-term photoinhibition and ameliorate photosynthetic performance, even if working in tandem with other photoprotection mechanisms.

DMSPt concentrations displayed only moderate changes ( $<5 \%$ variation in 13 out of 16 incubations) and no clear trends were found across treatments (data not shown). A strong DMSPt depletion in surface bottles was only found in $\mathrm{O} 2(21 \%)$. The stability of the DMSPt concentration across spectral irradiance treatments is notable, given that (1) a lower amount of fixed carbon was available for DMSP synthesis in surface and mixing samples, and (2) higher amounts of DMSP were lost as DMS (and perhaps as dimethylsulfoxide) at higher irradiance. The quotient of $\mathrm{GP}_{\mathrm{DMS}}$ to DMSPt was $0.42 \mathrm{~d}^{-1}, 0.29 \mathrm{~d}^{-1}, 0.18 \mathrm{~d}^{-1}$, and $0.21 \mathrm{~d}^{-1}$ on average in surface, middle, bottom and mixing bottles, respectively. These data suggest that faster DMSP synthesis was required to sustain DMSPt concentrations at high irradiance. Gross DMSP synthesis rates were not measured in our experiments, but, interestingly, experiment-normalized net DMSP synthesis rates and PPp were correlated (Pearson's $r=0.50$; $p=0.048$; Spearman's $\rho=0.65 ; p=0.006$ ). Recent results suggest that DMS can be produced intracellularly in phytoplankton through DMSP cleavage by $\mathrm{OH}$ radicals, without the need for DMSP cleavage enzymes (D. J. Kieber, personal communication, 2012). In addition, some algal strains can reduce dimethylsulfoxide back to DMS, potentially enhancing their antioxidant protection (Spiese et al., 2009). Since DMS is membrane-permeable, it is reasonable to assume that a significant fraction will escape the cell without being oxidized, so that DMSP will play a more direct and important 
role in antioxidant protection than in the original antioxidant hypothesis formulated by Sunda et al. (2002).

The similar short-term behavior of DMSPt in all the experiments contrasts with the differences in the ratios of total DMSP (DMSPt) to Chl $a$ between the coastal (DMSPt / Chl $a$ of 77-92 $\left.\mu \mathrm{mol} \mathrm{g}^{-1}\right)$ and the oceanic (196-315 $\left.\mu \mathrm{mol} \mathrm{g}^{-1}\right)$ settings. These differences may be explained by the presence of strong DMSP producers in $\mathrm{O} 1$ and $\mathrm{O} 2$, such as dinoflagellates and haptophytes. Besides taxonomy, also nutrient availability (particularly nitrogen) and the longer-term acclimation to elevated UVR and PAR contribute to regulate the DMSP content of phytoplankton (Bucciarelli and Sunda, 2003; Sunda et al., 2007; Archer et al., 2010). While the irradiance doses of the four upper mixed layers sampled were not significantly different (Table 1), lower nitrate concentrations in the open ocean waters might have contributed to set the higher DMSPt/Chl $a$ ratios found in $\mathrm{O} 1$ and $\mathrm{O} 2$ by simultaneously decreasing Chl $a$ and increasing DMSP cell quotas. Intriguingly, the DMSPt/Chl $a$ ratios at the end of the experiments showed an opposite pattern in $\mathrm{C} 1$ and $\mathrm{C} 2 \mathrm{com}$ pared to $\mathrm{O} 1$ and $\mathrm{O} 2$ (Fig. 4g). Overall, these results indicate that it is crucial to distinguish between short-term (hours) and long-term (days, weeks) responses if we are to understand the photophysiological mechanisms that drive DMS and DMSP cycling in phytoplankton cells and at the community level.

Net biological DMS production ( $\left.\mathrm{NP}_{\text {bio, } \mathrm{DMS}}\right)$ showed a pattern similar to that of $\mathrm{GP}_{\mathrm{DMS}}$ (Fig. $6 \mathrm{~b}$ ). $\mathrm{NP}_{\text {bio,DMS }}$ is interesting in that it tells the net effect of sunlight on biological DMS cycling, that is, on the difference between $\mathrm{GP}_{\mathrm{DMS}}$ and bacterial DMS consumption. Bacterial DMS consumption rates, calculated by subtracting $\mathrm{NP}_{\text {bio,DMS }}$ from $\mathrm{GP}_{\mathrm{DMS}}$, consumed on average $11 \%, 31 \%, 43 \%$ and $14 \%$ of $\mathrm{GP}_{\mathrm{DMS}}$ in surface, middle, bottom and mixing bottles, respectively. Thus, the imbalance between GP DMS and bacterial DMS consumption increased with spectral irradiance due to UV and/or PAR inhibition of bacterial DMS consumption and stimulation of $\mathrm{GP}_{\mathrm{DMS}}$, making the vertical gradient of $\mathrm{NP}_{\text {bio,DMS }}$ even larger than that of $\mathrm{GP}_{\mathrm{DMS}}$ (Fig. 6b). The net stimulating effect of sunlight on biological DMS production was largely compensated by DMS photolysis, so that net overall DMS concentration changes were close to zero in all treatments, as already observed by Galí et al. (2013a) with other experimental settings.

Bacterial DMS consumption, expressed as the \% of vertically integrated rates, was $49 \%, 79 \%, 125 \%$ and $78 \%$ in surface, middle, bottom and mixing bottles, respectively. Although these results suffer from a large uncertainty due to error propagation, they suggest that bacterial DMS consumption was more strongly inhibited than bulk LIR, and that it was photoinhibited in a dose-dependent manner. Severe photoinhibition was already observed by Toole et al. (2006), who reported a similar response of bacterial DMS consumption and LIR. Since only a portion of the bacterial community is able to consume DMS through oxidation, it is likely that the photoresponse of bacterial DMS consumers and that of bulk heterotrophic bacteria differ (as suggested by Galí and Simó, 2010) and also that the photoresponse of different metabolic activities differs in a given cell or strain. Clearly, these issues deserve further investigation.

\subsection{Differential irradiance- and dose-response among biogeochemical processes}

The experiment-normalized PPp, LIRs and community DMS production rates were plotted against the mean (UVB, UVA, PAR) incubation irradiance in the ensemble of all the experiments, and the points corresponding to fixed bottles were fitted with a linear regression (Fig. 7). We also calculated the Pearson correlation coefficient between the experimentnormalized process rates and (1) mean irradiance and (2) total irradiance dose for each radiation band (Fig. 8). The aim of this exercise was to identify whether a process was more dose-dependent or irradiance ("dosage-rate")-dependent, following the rationale exposed in the Introduction. Note that in our experimental setting it is hard to discriminate between the effects of each band of the spectrum, since the proportion of shortwave UV decreases along with total (or PAR) irradiance as we move deeper in the water column.

PPp showed a slight negative trend with respect to irradiance in fixed bottles in the three radiation bands, which was mainly driven by photoinhibition in surface bottles. In fact, the response was rather flat below an irradiance threshold of ca. $0.4 \mathrm{~W} \mathrm{~m}^{-2} \mathrm{UVB}, 16 \mathrm{~W}^{-2} \mathrm{UVA}$ and $1000 \mu \mathrm{mol}$ photons $\mathrm{m}^{-2} \mathrm{~s}^{-1}$. The correlation with irradiance was higher than that with dose (Fig. 8a), suggesting that some balance between inhibition and protection/repair could be attained in the different exposure regimes. The highest linear correlation was found with UVA irradiance, perhaps indicating that this band drives photoinhibition in UV-transparent waters. In concordance with this suggestion, some studies have shown that the spectral peak of UV photoinhibition occurs in the UVA, due to the combination of increasing irradiance and decreasing UV effectiveness as we move towards longer wavelengths (Neale and Kieber, 2000).

LIR decreased with increasing UVB, UVA and PAR with a slope very similar to that of PPp. Contrary to the other processes examined, the photoinhibition of LIR was more strongly correlated to the dose than to irradiance, particularly in the UVB band, suggesting that cumulative UVBinduced DNA damage occurred in bacterial cells in fixed incubations (Buma et al., 2001). This fits with the general idea that the radiation bands causing damage (UVB) elicit more dose-dependent responses than the radiation bands that are used by the cells to conduct physiological processes (PAR and longwave UVA).

Community DMS production rates showed a strong response to variations in spectral irradiance, with a steeper slope observed for $\mathrm{NP}_{\text {bio,DMS }}$ than for $\mathrm{GP}_{\mathrm{DMS}}$ (Fig. 7c, d). The strongest correlations were found between $\mathrm{GP}_{\mathrm{DMS}}$ and irradiance in the three bands, particularly in the UVA. This 


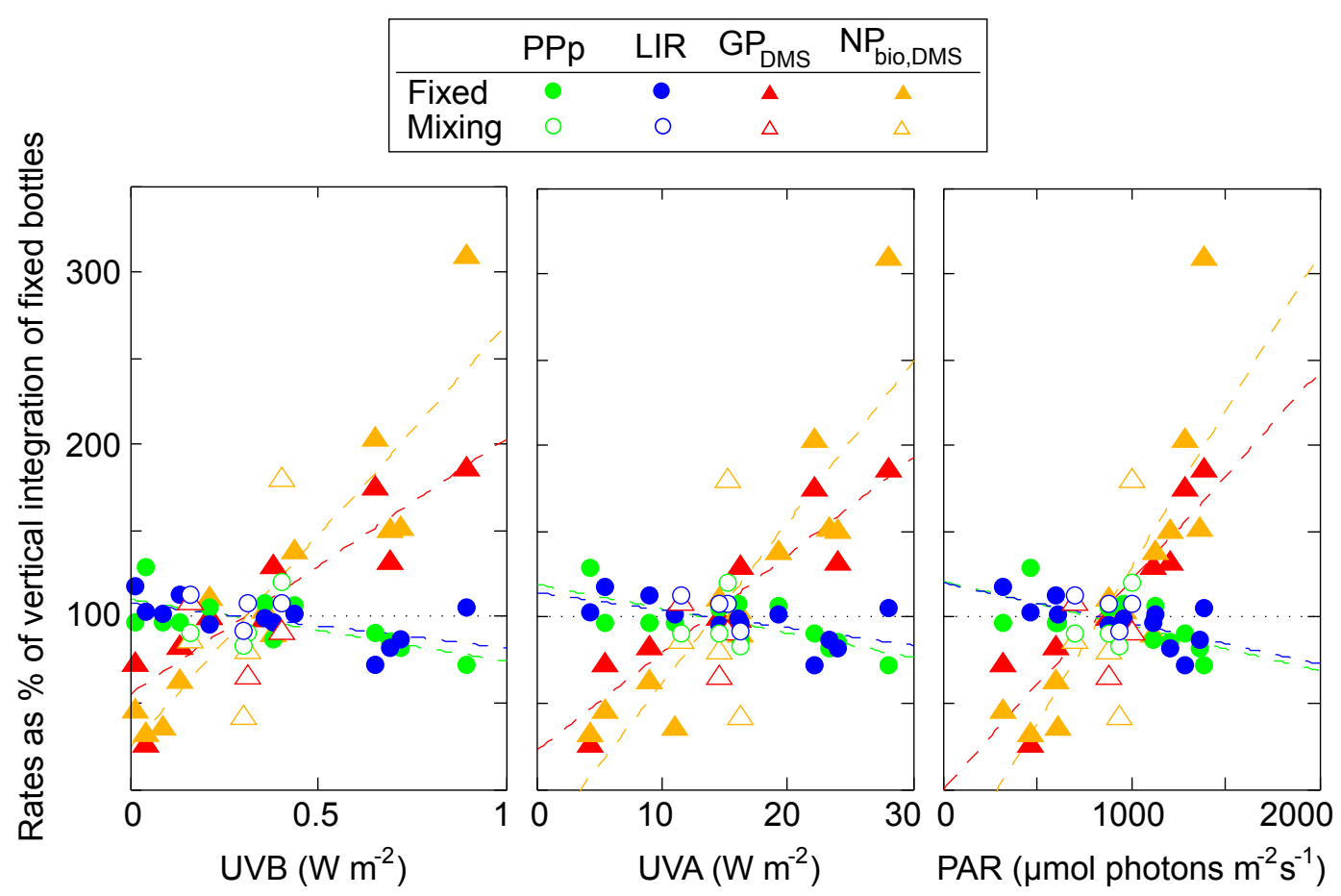

Fig. 7. Relationship between mean UVB, UVA and PAR irradiance during the incubations and particulate primary production (PPp), leucine incorporation rates (LIRs), gross DMS production $\left(\mathrm{GP}_{\mathrm{DMS}}\right)$ and net biological DMS production $\left(\mathrm{NP}_{\text {bio,DMS }}\right)$. The rates have been normalized to the vertical integral of fixed-depth incubations (see text). The lines represent linear least squares fits to the fixed-depth incubations only (filled symbols). Vertically moving incubations ("mixing", open symbols) have not been included in the regressions.

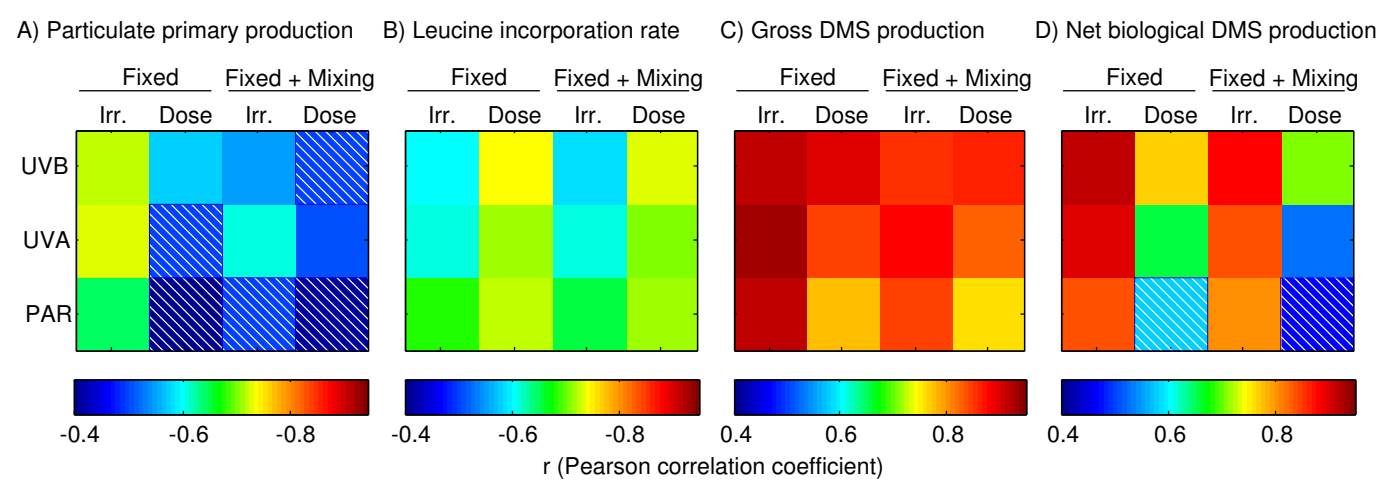

Fig. 8. Pearson's correlation coefficient $(r)$ between biogeochemical process rates and mean incubation irradiance (Irr.) or cumulative dose in different radiation bands (UVB, UVA and PAR), in fixed bottles only and in the ensemble of fixed + mixing bottles. Note that $r$ is negative in (a) and (b) and positive in (c) and (d). The diagonal stripe pattern indicates non-significant $r(p>0.05)$.

agrees with previous studies that suggested, using distinct approaches, that the spectral peak of sunlight-induced DMS production occurs in the $330-340 \mathrm{~nm}$ region in surface UVtransparent waters (Toole et al., 2008; Levine et al., 2012; Galí et al., 2013a).

Finally, note that among all process and radiation combinations (Fig. 8) the correlation was stronger when mixing bottles were excluded. This illustrates in a loose way that mixing subtly disrupted the photoacclimation and photodamage processes, as thoroughly discussed in Sects. 3.2-3.4.

The results presented here on the enhancement of DMS production by increased irradiance and relative UVB exposure agree with those recently reported by our group using a variety of approaches, from light spectrum manipulation with optical filters (Galí et al., 2013a) to the study of diel cycles at sea (Galí et al., 2013b). They all provide mechanistic bases to the role of solar radiation as the main driver of DMS 
production and concentration in the surface ocean (Vallina and Simó, 2007). In the short term (hours) sunlight directly affects the cellular machineries of DMS producers and DMS consumers, and favors DMSP-to-DMS conversion pathways; in the longer term (days to months) sunlight shapes the seasonality of the dynamics in upper-ocean physics and plankton succession, favoring DMSP producers. As a resulting emergent property, DMS tends to increase in summer even in regions where phytoplankton biomass is at its annual minimum. This phenomenon was termed the "DMS summer paradox" (Simó and Pedrós-Alió, 1999) and suggested to be at the base of a "seasonal CLAW" hypothesis by which plankton respond to higher summer irradiances by increasing the production of cloud-brightening DMS (Vallina and Simó, 2008). Whether this seasonal feedback will also operate efficiently at the longer timescale of anthropogenic global warming or Earth climate cycles cannot be easily predicted from short-term observations. Indeed, projections point to an enhancement, expansion and longer duration of stratification by global warming, with shallower mixed layers during longer periods (Sarmiento et al., 1998), which would result in increased exposures of plankton to UVR (Diaz et al., 2000). In view of our results, this might lead to increased DMS concentrations/emissions. However, the likely substitution of plankton species and communities by ones more adapted to the evolving conditions, and the development of protection strategies against environmental stress, hamper the straightforward applicability of our short-term observations to longterm trends.

\section{Conclusions}

The photoresponse of phytoplankton, bacterioplankton, and community DMS production displayed clear trends in bottles incubated at fixed depths in the UML (Fig. 7) despite the relatively small gradient in spectral irradiance. The irradiance dose response in mixing bottles was distinct (though subtle) in each of the processes measured, as well as for different physiological indicators. In the oligotrophic waters investigated, dynamic light exposure generally caused, compared to the middle bottles receiving the same cumulative exposure, (1) an adverse though non-significant effect on particulate primary production, concomitant with reduced cellspecific fluorescence in most experiments and phytoplankton groups; (2) a slightly alleviating effect on bacterial production photoinhibition, related to an increase in the proportion of intact-membrane, or live, heterotrophic bacteria in two of the experiments; and (3) a neutral effect or slight reduction in gross DMS production. These responses translated, in some experiments, into measurable deviations with respect to the vertically integrated rates in the water column; in others, the effects were close to neutral or too small to be reliably detected. Incubating the samples at a fixed intermediate optical depth appears as a reasonable and convenient solution for measuring $\mathrm{GP}_{\mathrm{DMS}}$ and leucine incorporation, at least in UVR-transparent stratified UML waters. However, this solution might not be optimal for measuring UML-integrated primary production. Our results call for a more systematic assessment of the consequences of dynamic light exposure of microbial plankton in different oceanic regimes. This way, the photobiological processes governing, among other important processes, the ocean-atmosphere exchange of longlived $\left(\mathrm{CO}_{2}\right)$ and short-lived (DMS) gases of climatic relevance will be better understood.

Acknowledgements. We thank the staff at Port Olímpic de Barcelona for their collaboration, and the crew and scientists aboard R/V García del Cid for their invaluable help in setting up the experiments during the SUMMER-I cruise. We also thank D. J. Kieber for his insightful comments on an earlier version of the manuscript, R. Bertoni for sharing his expertise, and two anonymous reviewers for their constructive suggestions. M. G. acknowledges the receipt of a CSIC JAE scholarship. This work was supported by the (former) Spanish Ministry of Science and Innovation through the project SUMMER (CTM2008-03309/MAR). This is a contribution of the Research Groups on Marine Biogeochemistry and Global Change and on Aquatic Microbial Food Webs, supported by the Generalitat de Catalunya.

Edited by: G. Herndl

\section{References}

Aas, P., Lyons, M., Pledger, R., Mitchell, D., and Jeffrey, W.: Inhibition of bacterial activities by solar radiation in nearshore waters and the Gulf of Mexico, Aquat. Microb. Ecol., 11, 229-238, doi:10.3354/ame011229, 1996.

Agogué, H., Joux, F., Obernosterer, I., and Lebaron, P.: Resistance of Marine Bacterioneuston to Solar Radiation, Appl. Environ. Microb., 71, 5282-5289, doi:10.1128/AEM.71.9.5282, 2005.

Alonso-Sáez, L., Gasol, J. M., Lefort, T., Hofer, J., and Sommaruga, R.: Effect of natural sunlight on bacterial activity and differential sensitivity of natural bacterioplankton groups in northwestern Mediterranean coastal waters, Appl. Environ. Microb., 72, 5806-5813, doi:10.1128/AEM.00597-06, 2006.

Archer, S. D., Cummings, D., Llewellyn, C., and Fishwick, J.: Phytoplankton taxa, irradiance and nutrient availability determine the seasonal cycle of DMSP in temperate shelf seas, Mar. Ecol. Prog. Ser., 394, 111-124, doi:10.3354/meps08284, 2009.

Archer, S. D., Ragni, M., Webster, R., Airs, R. L., and Geider, R. J.: Dimethyl sulfoniopropionate and dimethyl sulfide production in response to photoinhibition in Emiliania huxleyi, Limnol. Oceanogr., 55, 1579-1589, doi:10.4319/lo.2010.55.4.1579, 2010.

Asher, E. C., Dacey, J. W. H., Mills, M. M., Arrigo, K. R., and Tortell, P. D.: High concentrations and turnover rates of DMS, DMSP and DMSO in Antarctic sea ice, Geophys. Res. Lett., 38, 1-5, doi:10.1029/2011GL049712, 2011.

Barbieri, E. S., Villafañe, V. E., Helbling, E. W., and Nov, N.: Experimental assessment of UV effects on temperate marine phy- 
toplankton when exposed to variable radiation regimes, Limnol. Oceanogr., 47, 1648-1655, 2002.

Béjà, O., Aravind, L., Koonin, E. V., Suzuki, M. T., Hadd, A., Nguyen, L. P., Jovanovich, S. B., Gates, C. M., Feldman, R. A., Spudich, J. L., Spudich, E. N., and DeLong, E. F.: Bacterial Rhodopsin: Evidence for a New Type of Phototrophy in the Sea, Science, 289, 1902-1906, doi:10.1126/science.289.5486.1902, 2000.

Bertoni, R., Jeffrey, W. H., Pujo-Pay, M., Oriol, L., Conan, P., and Joux, F.: Influence of water mixing on the inhibitory effect of UV radiation on primary and bacterial production in Mediterranean coastal water, Aquat. Sci., 73, 377-387, doi:10.1007/s00027011-0185-8, 2011.

Brainerd, K. E. and Gregg, M. C.: Surface mixed and mixing layer depths, Deep Sea Res. Pt. I, 42, 1521-1543, 1995.

Bricaud, A., Babin, M., Morel, A., and Claustre, H.: Variability in the chlorophyll-specific absorption coefficients of natural phytoplankton, Analysis and parameterization, J. Geophys. Res., Oceans, 100, 13321-13332, doi:10.1029/95JC00463, 1995.

Brunet, C. and Lavaud, J.: Can the xanthophyll cycle help extract the essence of the microalgal functional response to a variable light environment?, J. Plankton Res., 32, 1609-1617, doi:10.1093/plankt/fbq104, 2010.

Bucciarelli, E. and Sunda, W. G.: Influence of $\mathrm{CO}_{2}$, nitrate, phosphate, and silicate limitation on intracellular dimethylsulfoniopropionate in batch cultures of the coastal diatom Thalassiosira pseudonana, Limnol. Oceanogr., 48, 2256-2265, doi:10.4319/lo.2003.48.6.2256, 2003.

Buma, A. G., Helbling, E. W., de Boer, M. K., and Villafañe, V. E.: Patterns of DNA damage and photoinhibition in temperate South-Atlantic picophytoplankton exposed to solar ultraviolet radiation, J. Photoch. Photobio. B, 62, 9-18, 2001.

Campbell, D., Eriksson, M. J., Oquist, G., Gustafsson, P., and Clarke, A. K.: The cyanobacterium Synechococcus resists UVB by exchanging photosystem II reaction-center D1 proteins, $\mathrm{P}$. Natl. Aca. Sci. USA, 95, 364-9, 1998.

Carpenter, L. J., Archer, S. D., and Beale, R.: Ocean-atmosphere trace gas exchange, Chem. Soc. Rev., 41, 6473-6506, 2012.

Church, M. J., Ducklow, H. W., and Karl, D. M.: Light dependence of $[3 \mathrm{H}]$ leucine incorporation in the oligotrophic North Pacific ocean, Appl. Environ. Microb., 70, 4079-87, doi:10.1128/AEM.70.7.4079-4087.2004, 2004.

Denman, K. L. and Gargett, A. E.: Time and space scales of vertical mixing in the upper ocean, Limnol. Oceanogr., 28, 801-815, 1983.

Diaz, S. B., Morrow, J. H., and Booth, C. R.: UV physics and optics, The effects of UV radiation in the marine environment, 35-71, 2000.

Galí, M. and Simó, R.: Occurrence and cycling of dimethylated sulfur compounds in the Arctic during summer receding of the ice edge, Mar. Chem., 122, 105-117, doi:10.1016/j.marchem.2010.07.003, 2010.

Galí, M., Saló, V., Almeda, R., Calbet, A., and Simó, R.: Stimulation of gross dimethylsulfide (DMS) production by solar radiation, Geophys. Res. Lett., 38, 1-5, doi:10.1029/2011GL048051, 2011.

Galí, M., Ruiz-González, C., Lefort, T., Gasol, J. M., Cardelús, C., Romera-Castillo, C., and Simó, R.: Spectral irradiance depen- dence of sunlight effects on plankton dimethylsulfide production, Limnol. Oceanogr., 58, 489-504, 2013 a.

Galí, M., Simó, R., Vila-Costa, M., Ruiz-González, C., Gasol, J. M., and Matrai, P.: Diel patterns of oceanic dimethylsulfide (DMS) cycling: Microbial and physical drivers, Glob. Biogeochem. Cy., 2013b.

Gallegos, C. L. and Platt, T.: Vertical advection of phytoplankton and productivity estimates: a dimensional analysis, Mar. Ecol. Prog. Ser., 26, 125-134, 1985.

Grégori, G., Citterio, S., Ghiani, A., Labra, M., Sgorbati, S., Brown, S., and Denis, M.: Resolution of viable and membranecompromised bacteria in freshwater and marine waters based on analytical flow cytometry and nucleic acid double staining, Appl Environ. Microb., 67, 4662-4670, 2001

Harada, H., Vila-Costa, M., Cebrian, J., and Kiene, R. P.: Effects of $\mathrm{UV}$ radiation and nitrate limitation on the production of biogenic sulfur compounds by marine phytoplankton, Aquat. Bot., 90, 37 42, 2009

Hefu, Y. and Kirst, G. O.: Effect of UV- radiation on DMSP content and DMS formation of Phaeocystis antarctica, Polar Biol., 18, 402-409, doi:10.1007/s003000050206, 1997.

Helbling, E. W., Carrillo, P., Medina-Sánchez, J. M., Durán, C., Herrera, G., Villar-Argaiz, M., and Villafañe, V. E.: Interactive effects of vertical mixing, nutrients and ultraviolet radiation: in situ photosynthetic responses of phytoplankton from high mountain lakes in Southern Europe, Biogeosciences, 10, 1037-1050, doi:10.5194/bg-10-1037-2013, 2013.

Helbling, E. W., Gao, K., Gonçalves, R., Wu, H., and Villafañe, V. E.: Utilization of solar UV radiation by coastal phytoplankton assemblages off SE China when exposed to fast mixing, Mar. Ecol. Prog. Ser., 259, 59-66, doi:10.3354/meps259059, 2003.

Kaiser, E. and Herndl, G. J.: Rapid Recovery of Marine Bacterioplankton Activity after Inhibition by UV Radiation in Coastal Waters, Appl. Environ. Microb., 63, 4026-4031, 1997.

Kirchman, D., K'nees, E., and Hodson, R.: Leucine incorporation and its potential as a measure of protein synthesis by bacteria in natural aquatic systems, Appl. Environ. Microbiol., 49, 599-607, 1985

Kirchman, D. L. and Hanson, T. E.: Bioenergetics of photoheterotrophic bacteria in the oceans, Environ. Microbiol. Rep., 5, 188-199, doi:10.1111/j.1758-2229.2012.00367.x, 2012.

Kolber, Z., Van Dover, C., Niederman, R., and Falkowski, P.: Bacterial photosynthesis in surface waters of the open ocean, Nature, 407, 177-179, 2000.

Lana, A., Bell, T. G., Simó, R., Vallina, S. M., Ballabrera-Poy, J., Kettle, A. J., Dachs, J., Bopp, L., Saltzman, E. S., Stefels, J., Johnson, J. E., and Liss, P. S.: An updated climatology of surface dimethlysulfide concentrations and emission fluxes in the global ocean, Global Biogeochem. Cy., 25, 1-17, doi:10.1029/2010GB003850, 2011.

Levine, N. M., Varaljay, V. A., Toole, D. A., Dacey, J. W. H., Doney, S. C., and Moran, M. A.: Environmental, biochemical and genetic drivers of DMSP degradation and DMS production in the Sargasso Sea, Environ. Microbiol., 14, 1210-1223, doi:10.1111/j.1462-2920.2012.02700.x, 2012.

MacIntyre, H. L., Kana, T. M., Anning, T., and Geider, R. J.: Photoacclimation of photosynthesis irradiance response curves and photosynthetic pigmentspigments in microalgae and cyanobacteria, J. Phycol., 38, 17-38, 2002. 
Marie, D. and Partensky, F.: Analyse de micro-organismes marins, in: La cytométrie en flux, edited by: Ronot, X., Grunwald, D., Mayol, J. F., and Boutonnat, J., Lavoisier, 211-233, 2006.

Mitchell, B., Bricaud, A., Carder, K., Cleveland, J. S., F., G. M., and Gould, R.: Determination of spectral absorption coefficients of particles, dissolved material and phytoplankton for discrete water samples, in: Ocean Optics Protocols for Satellite Ocean Color Sensor Validation, Revision 2, edited by: Fargion, G., Mueller, J., and McClain, C., NASA, 125-153, 2000.

Mitchell, B. G. and Kiefer, D. A.: Determination of absorption and fluorescence excitation spectra for phytoplankton, in: Marine Phytoplankton and Productivity, edited by: Holm-Hansen, O., Bolis, L., and Giles, R., 157-169, Springer, 1984.

Morán, X. A. G., Gasol, J. M., Arin, L., and Estrada, M.: A comparison between glass fiber and membrane filters for the estimation of phytoplankton POC and DOC production, Mar. Ecol. Prog. Ser., 187, 31-41, 1999.

Morán, X. A. G., Massana, R., and Gasol, J. M.: Light Conditions Affect the Measurement of Oceanic Bacterial Production via Leucine Uptake, Appl. Environ. Microb., 67, 3795-3801, doi:10.1128/AEM.67.9.3795-3801.2001, 2001.

Neale, P. J. and Kieber, D. J.: Assessing Biological and Chemical Effects of UV in the Marine Environment: Spectral Weighting Functions, Issues in Environmental Science and Technology, 2000.

Neale, P. J., Helbling, E. W., and Zagarese, H. E.: Modulation of UVR exposure and effects by vertical mixing and advection, in: UV effects in aquatic organisms and ecosystems, The Royal Society of Chemistry Cambridge, 107-134, 2003.

Quinn, P. K. and Bates, T. S.: The case against climate regulation via oceanic phytoplankton sulphur emissions, Nature, 480, 51-6, doi:10.1038/nature10580, 2011.

Ross, O. N., Geider, R. J., Berdalet, E., Artigas, M. L., and Piera, J.: Modelling the effect of vertical mixing on bottle incubations for determining in situ phytoplankton dynamics. I. Growth rates, Mar. Ecol. Prog. Ser., 435, 13-31, doi:10.3354/meps09193, 2011a.

Ross, O. N., Geider, R. J., and Piera, J.: Modelling the effect of vertical mixing on bottle incubations for determining in situ phytoplankton dynamics Pt.II., Primary production, Mar. Ecol. Prog. Ser., 435, 33-45, doi:10.3354/meps09194, 2011b.

Roy, S.: The strategies for minimization of UV damage, in: The Effects of UV Radiation in the Marine Environment, edited by: de Mora, S. J., Demers, S., and Vernet, M., chap. 3, 177-205, Cambridge University Press, Cambridge, 2000.

Ruiz-González, C., Galí, M., Lefort, T., Cardelús, C., Simó, R., and Gasol, J. M.: Annual variability in light modulation of bacterial heterotrophic activity in surface northwestern Mediterranean waters, Limnol. Oceanogr., 57, 1376-1388, doi:10.4319/lo.2012.57.5.1376, 2012.

Ruiz-González, C., Simó, R., Sommaruga, R., and Gasol, J. M.: Away from darkness: A review on the effects of solar radiation on heterotrophic bacterioplankton activity, Front. Microbiol., 4, 131, doi:10.3389/fmicb.2013.00131, 2013.

Saló, V., Simó, R., and Calbet, A.: Revisiting the dilution technique to quantify the role of microzooplankton in $\mathrm{DMS}(\mathrm{P})$ cycling: laboratory and field tests, J. Plankton Res., 32, 1255-1267, doi:10.1093/plankt/fbq041, 2010.
Sarmento, H. and Gasol, J. M.: Use of phytoplankton-derived dissolved organic carbon by different types of bacterioplankton., Environ. Microb., 14, 2348-60, doi:10.1111/j.14622920.2012.02787.x, 2012.

Sarmiento, J. L., Hughes, T. M., Stouffer, R. J., and Manabe, S.: Simulated response of the ocean carbon cycle to anthropogenic climate warming, Nature, 393, 245-249, 1998.

Shick, J. M. and Dunlap, W. C.: Mycosporine-like amino acids and related Gadusols: biosynthesis, acumulation, and UV-protective functions in aquatic organisms, Ann. Rev. Physiol., 64, 223-62, doi:10.1146/annurev.physiol.64.081501.155802, 2002.

Simó, R.: From cells to globe : Approaching the dynamics of DMS(P) in the ocean at multiple scales, Can. J. Fish. Aquat. Sci., 61, 673-684, doi:10.1139/F04-030, 2004.

Simó, R. and Pedrós-Alió, C.: Role of vertical mixing in controlling the oceanic production of dimethyl sulphide, Nature, 402, 396399, 1999.

Simó, R., Pedrós-Alió, C., Malin, G., and Grimalt, J. O.: Biological turnover of DMS, DMSP and DMSO in contrasting open-sea waters, Mar. Ecol. Prog. Ser., 203, 1-11, doi:10.3354/meps203001, 2000.

Simó, R., Vila-Costa, M., Alonso-Sáez, L., Cardelús, C., Guadayol, O., Vázquez-Domínguez, E., and Gasol, J.: Annual DMSP contribution to $\mathrm{S}$ and $\mathrm{C}$ fluxes through phytoplankton and bacterioplankton in a NW Mediterranean coastal site, Aquat. Microb. Ecol., 57, 43-55, doi:10.3354/ame01325, 2009.

Slezak, D. and Herndl, G.: Effects of ultraviolet and visible radiation on the cellular concentrations of dimethylsulfoniopropionate (DMSP) in Emiliania huxleyi (strain L), Mar. Ecol. Prog. Ser., 246, 61-71, doi:10.3354/meps246061, 2003.

Smith, D. C. and Azam, F.: A simple, economical method for measuring bacterial protein synthesis rates in seawater using $3 \mathrm{H}-$ leucine, Marine Microbial Food Webs, 6, 107-114, 1992.

Sommaruga, R., Hofer, J. S., Alonso-Saez, L., and Gasol, J. M.: Differential sunlight sensitivity of picophytoplankton from surface Mediterranean coastal waters, Appl. Environ. Microb., 71, 2154-2157, doi:10.1128/AEM.71.4.2154, 2005.

Spiese, C., Kieber, D. J., Nomura, C., and Kiene, R. P.: Reduction of dimethylsulfoxide to dimethylsulfide by marine phytoplankton, Limnol. Oceanogr., 54, 560-570, 2009.

Stefels, J.: Physiological aspects of the production and conversion of DMSP in marine algae and higher plants, J. Sea Res., 43, 183 197, doi:10.1016/S1385-1101(00)00030-7, 2000

Sunda, W., Kieber, D. J., Kiene, R. P., and Huntsman, S.: An antioxidant function for DMSP and DMS in marine algae., Nature, 418, 317-20, doi:10.1038/nature00851, 2002.

Sunda, W. G., Hardison, R., Kiene, R. P., Bucciarelli, E., and Harada, H.: The effect of nitrogen limitation on cellular DMSP and DMS release in marine phytoplankton: climate feedback implications, Aquat. Sci., 69, 341-351, doi:10.1007/s00027-0070887-0, 2007.

Toole, D. A., Slezak, D., Kiene, R. P., Kieber, D. J., and Siegel, D. A.: Effects of solar radiation on dimethylsulfide cycling in the western Atlantic Ocean, Deep Sea Res. Pt. I, 53, 136-153, 2006.

Toole, D. A., Siegel, D. A., and Doney, S. C.: A lightdriven, one-dimensional dimethylsulfide biogeochemical cycling model for the Sargasso Sea, J. Geophys. Res., 113, 1-20, doi:10.1029/2007JG000426, 2008. 
Vallina, S. M. and Simó, R.: Strong relationship between DMS and the solar radiation dose over the global surface ocean., Science, 315, 506-508, doi:10.1126/science.1133680, 2007.

Vallina, S. M. and Simó, R.: Re-visiting the CLAW hypothesis, Environ. Chem., 4, 384-387, 2008.

van de Poll, W. H. and Buma, A. G. J.: Does ultraviolet radiation affect the xanthophyll cycle in marine phytoplankton?, Photochem. Photobiol. Sci., 8, 1295-1301, doi:10.1039/B904501E, 2009.

van Rijssel, M. and Buma, A.: UV radiation induced stress does not affect DMSP synthesis in the marine prymnesiophyte Emiliania huxleyi, Aquat. Microb. Ecol., 28, 167-174, doi:10.3354/ame028167, 2002.

Vila-Costa, M., Kiene, R. P., and Simó, R.: Seasonal variability of the dynamics of dimethylated sulfur compounds in a coastal northwest Mediterranean site, Limnol. Oceanogr., 53, 198-211, 2008.

Vincent, W. F. and Neale, P. J.: Mechanisms of UV damage to aquatic organisms, in: The Effects of UV Radiation in the Marine Environment, edited by de Mora, S. J., Demers, S., and Vernet, M., chap. 6, 149-176, Cambridge University Press, Cambridge, 2000.
Wolfe, G. and Kiene, R. P.: Radioisotope and chemical inhibitor measurements of dimethyl sulfide consumption rates and kinetics in estuarine waters, Mar. Ecol. Prog. Ser., 99, 261-269, 1993.

Woodhouse, M. T., Mann, G. W., Carslaw, K. S., and Boucher, O.: Sensitivity of cloud condensation nuclei to regional changes in dimethyl-sulphide emissions, Atmos. Chem. Phys., 13, $2723-$ 2733, doi:10.5194/acp-13-2723-2013, 2013.

Yang, G., Li, C., and Sun, J.: Influence of salinity and nitrogen content on production of dimethylsulfoniopropionate (DMSP) and dimethylsulfide (DMS) by Skeletonema costatum, Chin. J. Oceanol. Limn., 29, 378-386, 2011.

Zapata, M., Rodríguez, F., and Garrido, J. L.: Separation of chlorophylls and carotenoids from marine phytoplankton: a new HPLC method using a reversed phase C8 column and pyridinecontaining mobile phases, Mar. Ecol. Prog. Ser., 195, 29-45, doi:10.3354/meps 195029, 2000. 